\title{
Application of Selected Outcomes from PISA and PIAAC Researches to Czech Curriculum and Reading Education
}

\author{
Stefan Chudy ${ }^{*}$, Dana Vicherková \\ Department of Pedagogy and Social Sciences, Faculty of Education, Palacky University, Czech Republic
}

Copyright $\bigcirc 2016$ by authors, all rights reserved. Authors agree that this article remains permanently open access under the terms of the Creative Commons Attribution License 4.0 international License.

\begin{abstract}
This article deals with problematic fields which influence the level of reading strategies of fifteen to nineteen years old pupils (e.g. selected productive learning activities, work with diverse types of texts and information sources etc.). Moreover, the paper provides information about efficiency testing of pupils in selected reading strategies during entrance examination to high school and high school graduation exams. What is the connection between the trends in the Czech and foreign curriculum based upon the PISA and PIAAC outcome application? The aim of this paper is the reflection and analysis of key issues of the functional reading literacy, the methods employed were: content analysis of a selected part of the Czech curriculum, outcome comparison of international reading literacy researches PISA and PIAAC, reflection and analysis of approaches to test tasks for entrance examination to high school. This paper points out the complexity of curricular system, i.e. interdependence of primary, secondary and lifelong reading education.
\end{abstract}

Keywords Functional Reading Literacy, Functional Reading Strategy, Curriculum Documents, Difficulties in Education of a Reader, Didactical Test

\section{Introduction}

Dynamic progress in research of reading literacy of pupils and adults is taking place in the $21^{\text {st }}$ century. Both of these research fields reflect the demands for text comprehension of nowadays society. The research PISA shows difference in educational systems of participating countries (e.g. results, equality of access to education). According to PISA there is a weak dependency between socioeconomic background and the results of pupils. This evidence tells us that educational system is just to the pupils ant it gives them equal opportunities for education. The Czech Republic (CR) belongs to the group of countries with below average results in researches of reading literacy. At the same time CR belongs to countries with substandard value of index of Social Economic and Cultural Status (ESCS). This paper provides information about the steps taken by $\mathrm{CR}$ to improve the current status. Education is nowadays considered to be a lifelong process in CR. Work with text and its comprehension are important aspects of this process. The research PISA is based on a sample of fifteen-years-olds, whereas the research PIAAC is based on the sample of adult population. This research is based on the sample of pupils finishing their obligatory elementary education (15 years old) and their development from entrance examination to state exam (GCSE). That is the age of transition from childhood to adulthood.

\section{Reading Literacy as an Important Component of Key Competencies}

The reading literacy can be perceived as an important component of key competencies which is an entering way to acquire and develop many necessary competencies for everyday learning and coping with everyday life situations. Developing reading strategies according to adequate age and individual pupil's needs and at the same time being in compliance with the increasing demands of the society education level of the $21^{\text {st }}$ century, belongs to the fundamental duties of nowadays civilization. To be a sufficiently mature reader means to diminish studying problems in the lifelong learning process and education. This is being reflected on the person's success at the labor market. The research discusses the problematic age group of pupils at the end of the compulsory education in the transition period from a primary school to a high school. At this point the research deals with the adequate cooperation and continuity of the Educational Framework Program for Primary Schools and the Educational Framework Program for High schools with GCSE in the field of education with regard to reading. Furthermore the research focuses on the relationship between the curriculum documents of the Framework Educational Program Czech Language and Literature requirements in the field of reading literacy, 
reading strategies and concrete testing assignments as being part of the entrance exams from Czech Language and Literature for fifteen years old pupils during their transition to a high school.

The key question of the research is "What important milestone is the period when finishing high school education in terms of educating a reader?" At this point the research is focused on a concept of a new perception of the Czech state exam (GCSE) from Czech Language and Literature and is concentrating on the analysis of chosen parts of the curriculum documents of high school education (Catalogue of exam requirements with a common part of the Czech state examination from Czech Language and Literature, 2016) [1]. To what extent are the results of the found out outputs from the international surveys on reading literacy as well as functional literacy reflected in the Czech curriculum? Not only the ability to read a text technically correct is included to key problems of the survey on reading literacy but for the most to read it in a functional way (to concrete everyday communication situation). We are interested whether functional understanding of reading literacy is a key question characteristic of the educational curriculum in the Czech Republic as well as in the world curriculum trend and to what extent they proceed from the outputs of the international survey on reading literacy (PISA and PIAAC).

"Functional literacy-skills for the implementation of various human activities necessary for life in contemporary society. It's literacy in the field of literary work, documentary, and numerical, for example, the ability not only to read, but also to understand complex texts, fill in forms, to understand graphs, tables" [2].

According to the definition of literacy (according to OECD PISA), it is the skill in understanding a written text, thinking about it, and using it to achieve certain goals, to develop own abilities and knowledge, and for active integration into society [3].

Comprehension of a text from the cognitive taxonomy of educational objectives point of view (B. S. Bloom, in P. Gavora) [4] and from the point of view of the Bloom's revised taxonomy of educational objectives (L. W. Anderson; D. R. Krathwohl (eds.), in L. Liptáková and col) [5] in the paper were chosen cognitive objectives. Cognitive domain is specified in two dimensions (dimension of knowledge and dimension of a cognitive process). Four categories are differentiated in the dimension of knowledge: factual knowledge (ex. grammar), conceptual (ex. rules), procedural (ex. cohesion and coherence), metacognitive (ex. planning of an own cognition). At the second level (cognitive process) six categories are distinguished which are being expressed by active verbs (in the original taxonomy it was not about verb expression), they can be suitably used while formulating educational objectives - to remember, understand, apply, analyze, evaluate, create.
Understanding is dealt with in the category specifying manners of construction of a meaning on the bases of lessons learned through interpretation (explanation, paraphrasing), exemplifying, classifying, (integration, classification, categorizing), summarizing (abstracting, generalizing), judging (inferring, deducing conclusions, predicting), comparing (distinguishing, contrasting, matching) and explaining [5].

The organizer of the international survey PISA (2009) and PIAAC (2011/2012) is the Organization for Economic Co-operation and Development (OECD) [6]. Both surveys reflect the demands of the society for the desired skills necessary for an effective ordinary life as well as for success at the labor market. The aim of PISA survey was to find out whether pupils of the participating countries at the survey, acquired at the end of the compulsory education the knowledge and skills necessary for their success in the real environment of the society of the new millennium. The aim of the PIAAC survey was to find out the adult population readiness level for a life in modern society. This study is dedicated only to the field of examination of the reading literacy with regard to the informative outputs of the international inquiries.

Part of the examining activities of the PISA inquiry (in the form of a test) are: acquiring information, processing of information and an evaluation of the information. PIAAC inquiry deals with similar examined fields (but with greater overlap due to the age of the target adult population): reading, looking for facts, using computers and technologies, working experience, the course of the initial and further education. At this point two ways of examining are being used: test and questionnaire. Since the main findings of both international surveys was contradictory, especially in the limited sample of pupils at the border of a childhood and adulthood (15-24 years old), the purpose of this paper is to identify whether in the curriculum of the Czech Rep. as well as in the Czech pedagogical educational pedagogy itself, identical examining activities as well as examining tools like in the international inquiries are used while finding out the results of the surveys on reading literacy. Meaning, whether or not and how the Czech Republic is learning from the outputs of the international surveys on reading literacy.

PISA (2009) main findings: Czech pupils achieved only a below-averaged result in reading literacy test. The Czech Republic belongs to the five OECD countries in which can be seen since the year 2000 a significant deterioration. Czech fifteen years old pupils don't know how to well process facts, compare, analyze and interpret. These pupils are successful in searching for information.

PIAAC (2011/2012) main findings: The inquiry portrayed deteriorated results of the youngest age group of the adult population ( $16-24$ years old) in the same way as in other developed countries, but yet the youngest adult group is assessed to be at least at an average [7]. Nowadays $\mathrm{CR}$ is trying to find ways to improve the position of reading 
literacy among the member states of OECD by changing its curriculum[8].

\section{Perception of the Czech Curriculum in the Field of a Reading Literacy Development}

Are our official declared objectives of the school policy in the field of literacy development in compliance with the European and the whole world's perception? To the effective revised document Framework Educational Program for Primary Education [9] a fundamental curriculum educational document (attachment 1) called Standards for Primary Education is being attached. In our inquiry we first of all concentrate on the text analysis, where a target group is fifteen years old pupils at the second level of a primary school attending grade 9 .

A specific (independently formulated) emphasis on the reading strategy development is not being placed at the current and inforce curriculum conception in the didactical subject in the field of teaching the Czech mother language, it is only about an inseparable part of the communication competencies which is being evident from the analysis of the chosen problematic patterns in the document Standards for Primary Education in the Czech Language and literature, according to the inforce revision and adjustments [9]. This document includes three thematic subjects: 1 . Communication and composition education (with ten expected didactical outputs), 2. Language education (with eight expected didactical outputs) and 3. Literature education (with nine expected didactical outputs). It is possible to state that all of the three subjects of the analyzed document devote at varying degrees (in content as well as in the form) to the education in reading.

Selecting out of the $1^{\text {st }}$ thematic subjects, communication and composition education, for example in the expected outputs of the RVP ZV Czech Language and Literature $-9-1-07$ the pupil is supposed to join the discussion, lead it and use the principle of communication and the dialogue rules. One of the offered options is the dramatization of the episode text. The basis of communication is a dialogue having an interactive character [10].

\section{Sample of an illustrative task:}

"Read the extract written according to the book called Hobbit. Translate the part where the hobbit Bilbo talks with the imprisoned dwarf chief Thorin into a dialogue. Place into the dialogue everything they had to tell each other in order for Bilbo to pass on the message described below. Thorin was so wearied that he didn't even get angry at his bad lack, he even began to think that he is going to tell the king everything about his treasure, at this moment he suddenly heard Bilbo's voice at the keyhole. He could hardly believe it. He came to the door and was whispering on the other side with the hobbit for a long time... And so the hobbit Bilbo could pass on Thorin's message to other dwarfs. He told them that the chief Thorin is also close in the prison and that nobody of them should tell the king the aim of their travel until Thorin gives them an instruction to do so. The thing is that Thorin didn't want to promise to the king a share of the treasure until all the hope for rescue is gone..." [9], pg. 34.

Productive activity of a pupil from the moment of reading the text until the transformation of the text to a dialogue, using a direct speech and adequate choice of key words is the output of a reading strategy defined as the ability to choose and process the required information. A contact with the reader (the public) and the right understanding of the communication situation, the characteristics of the characters, time as well as place of the plot is considered as a positive phenomenon at the reading training. The pupil is able to "key out" the significant information toward the comprehension of the text, which is a demonstration of the level of critical thinking.

The expected output of the RVP CV 3. Literature education ČJL-9-3-5 belongs to the most demanding activities in the field of reading education. The aim for the pupil is to distinguish the value and the consumer literature also with an own argument assessment. In the illustrative task, the pupil is to express an opinion toward the assessment for the choice of characters or a place where the plot is occurring.

Sample of an illustrative task:

"Think about and explain how you like in the proposed text the choice of characters or a place where the story is taking place. Approximately two hours after sirens unicorns had arrived. There were only four, three out of the four were young. They moved proudly to their teacher and they curiously were looking around the surrounding. One of them was very familiar to Hanka. P'ujibo, it must be P'ujibo, she rejoiced quietly in her head that she could remember his name and she smiled at him. I greet you as well, she had heard his voice in her head. She was happy that he reacted and that he noticed her. You see, how small the world is, she thought to herself. Dragons arrived just before the nightfall. They welcomed each other with the school staff on the yard, they disappeared to a cliff over the river, a while before children could come closer and have a look at them. Hanka only counted them and there were seven of them. The next day the professors. Ferinova distributed to them red belts for hands. "To make sure that it is obvious that you are assigned as an accompanying service for the dragons." [9], pg. 50.

The expected output RVP ZV Czech Language and Literature -9-3-08 are considered as the most demanding activities requiring a higher degree of experience and knowledge in literature. The pupil is on the basis of the 
readings and watching a filmed literal adaptation of the work, comparing different renderings of the same topic. The pupil works with the information, analyzes it, compares and assesses it. $\mathrm{He} / \mathrm{she}$ expresses critically, why he/she prefers literal, filmed, dramatic composition of the work (in other case, why he/she accepts more ways of processing the same topic). An important question is in the illustrative task (e.g. in what way you liked it, in what way you liked the book) which leads to thinking about concrete phenomenon creating the pupil's subjective attitude, judgment, argument (i.e. expression of pupil's personality).

Sample of an illustrative task:

"Chose a book which you have read and which was being processed into a film, watch the film and write in what way you liked the film more and in what way you liked the book more." [9], pg. 53.

\section{Issues with Testing Fifteen Years Old Pupils during the Entrance Exams from the Czech Language and Literature}

Analysis of chosen assignments of the testing tasks in the field of reading strategies was part of the entrance exams to a high school in 2015, indicating which types of assignments were created by rigors in comprehension of a text. In 2015 the educational company CERMAT (Center for detecting results in education) had prepared pilot tests for entrance proceedings to high schools having the Czech state exams. It is about single didactical tests from the Czech language and literature for pupils in grade 9. Didactical test verifies handling of the basic language (grammar) rules, basic characteristics of the Czech grammar system, adoption of the basic reading strategies and stylistic basics of the mother tongue. Furthermore, the test verifies mastering of the sentence structure texts (artistic and non-artistic). With regard to the type of testing tasks an assignment of tasks with choosing the answers (tightly opened tasks) is used, matching tasks, dichotomous tasks in bunches, arranging tasks, closed tasks. Didactical text contains various types of texts (texts of different functional styles). In the field of Czech grammar there is the predomination of assigning tasks with the spelling characteristics, morphology, and word formation as well as it is in the field of syntax. From our point of view there are important tasks which are put into the problematic reading literacy (reading abilities). Assignments of the tasks test the understanding of the meaning of words, sentences, furthermore understanding the text, comparing information, finding out of information. In the area of the construction of the text it is about the text linguistic correctness and assessment of how the text is built, the pupil should recognize the type of text and orientation in the text structure.

In the sample of an illustrative task, the assignment of the didactical test for the entrance exams to a high school having the Czech state exams (studying for four years, www.novamaturita.cz, 2015) [1] is about the type of closed, matching tasks. The task for the pupil is to understand the meaning of the sentence unit, find out the required information, and understand the meaning of the text as well as of individual words. The pupil works with information in the given text, using reading strategies.

\section{TEXT FOR TASK 29}

From the interview with Arnošt Lustig

Redactor: When were you the closest to death during the war?

Arnošt Lustig: ***** (www.kinobox.cz, adjusted)

Which of the following belongs to the blank space (*****) in the text and thus is the answer to the redactor's question?

A) In Auschwitz, we were in a special quarantine ready to be gassed, they didn't even do the tattoo to us. B) A comrade came from the central committee and he had asked us, who agrees with the execution of the state betrayer Mrs. Milada Horáková.

C) We stopped praying when we had seen from the concentration camps the SS men how they burn the bodies of toddlers in the eight meters deep holes.

D) In prison we heard a story about a beautiful Polish woman sentenced to death, how she had grabbed the gun from the officer's hands, shot him and moreover wounded his adjutant." [1]

\subsection{Specification of the Didactical Test from Czech Language and Literature for Grade 9 [1]}

(Being part of the entrance exams to a high school) Number of tasks: 30, out of that 6 open and 24 closed tasks

Number of points: 50

Time: 60 minutes

Table 1. Types of tasks and their representation in the test (According to Zíka, J. (2015) [11]

\begin{tabular}{|c|c|c|c|c|c|}
\hline \multirow{2}{*}{ Tasks } & \multirow{2}{*}{$\begin{array}{c}\text { Number of } \\
\text { tasks }\end{array}$} & \multirow{2}{*}{ Types of tasks } & \multirow{2}{*}{$\begin{array}{c}\text { Number of } \\
\text { tasks }\end{array}$} & \multicolumn{2}{|c|}{ Representation in the test } \\
\hline & & & & $\%$ & points \\
\hline Open tasks & 6 & productive & 6 & $30 \%$ & 15 \\
\hline \multirow{4}{*}{ Closed tasks } & \multirow{4}{*}{24} & tasks multiple-choice with the choice of 4 alternatives & 17 & $34 \%$ & 17 \\
\hline & & Dichotomous tasks & 4 & $16 \%$ & 8 \\
\hline & & Matching tasks & 2 & $14 \%$ & 7 \\
\hline & & Arranging tasks & 1 & $6 \%$ & 3 \\
\hline TOTAL & 30 & & 30 & $100 \%$ & 50 \\
\hline
\end{tabular}




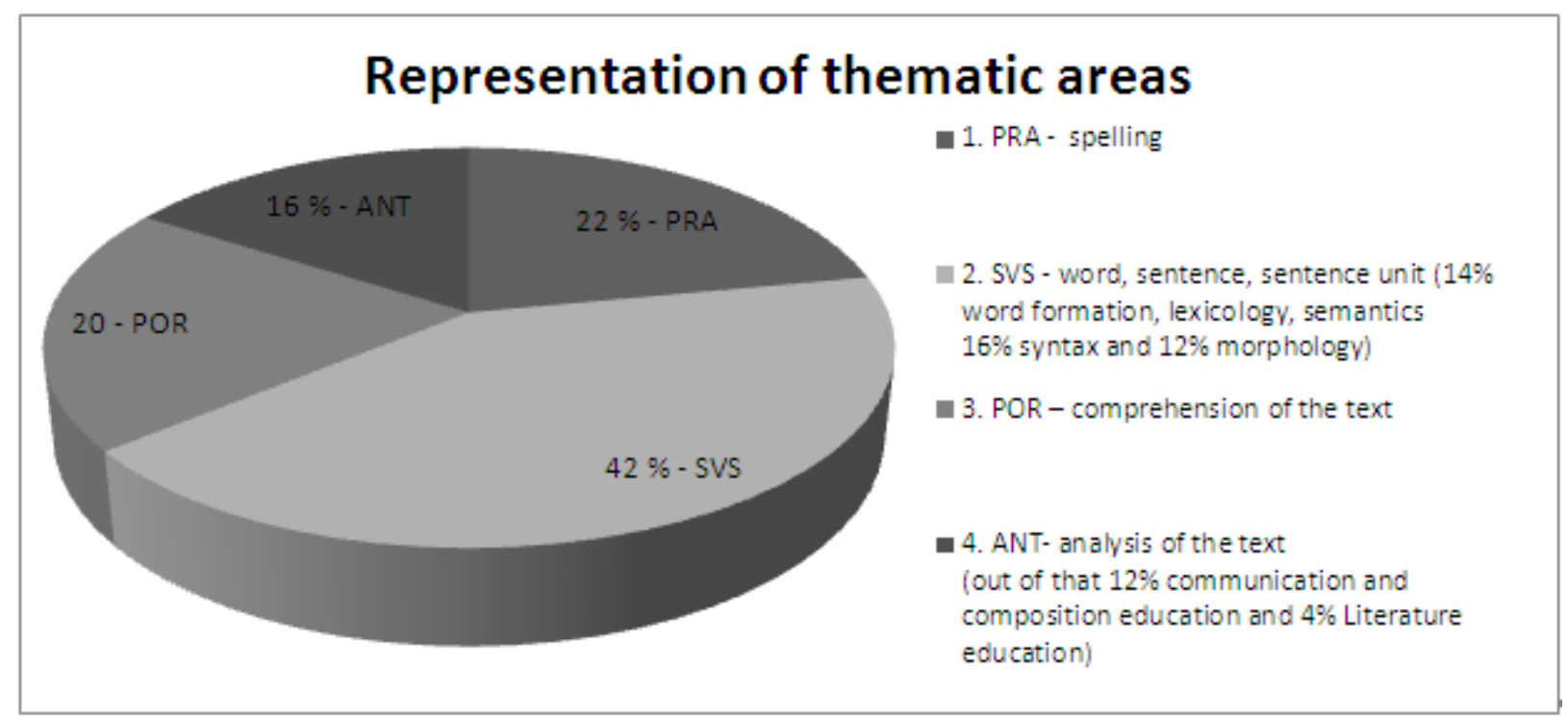

Graph 1. Representation of thematic areas (According to Zíka, J. (2015) [11]

\section{Output from the Requirements Catalogue for 2016}

Dynamic development in the education concept of the unified Czech state exam from Czech Language and Literature brings new information due to the survey and analysis of the curriculum documents of the high school education.

"On 30. 4. 2013, the Ministry of education, youth and sports (in accordance with Act No. 561/2004 Coll., On preschool, primary, secondary, higher professional, and other education - the Education Act, as amended by subsequent documents), catalogues tests required for school-leaving examinations in foreign languages, mathematics, and Czech language and literature. With the above requirements (in catalogue) will be tests and sub-tests of school-leaving examinations held after 1. 1. 2015.

Catalogues are mandatory educational documents that are based on the framework of educational programmes for secondary schools and general educational programmes for the fields of secondary vocational education with school (effective from 2007), and valid teaching documents for secondary vocational schools. In the preparatory process, catalogues were also based on the Standard of Secondary Vocational Education, issued by VÚOŚ Prague (with effect from 1. 1. 1998). " [12], pg. 54

By publishing the Catalogue of requirements for examinations with a common part for the Czech state examination from the Czech Language and Literature for 2016, a consolidated structure of a text of the Czech state exam from the Czech Language and literature is taking place. This makes it possible to implement and maintain a yearly comparison of examination tasks and assignments [1].
The new form of the Czech state exam from the Czech Language and Literature has a five years old tradition (since 2011). Pupils who finish their secondary education by the Czech state exam have a duty to undergo a complex state processed and guaranteed exam from the Czech Language and Literature in three parts. These are the following a didactical test, written composition work and an oral exam. Reading strategies are verified by various degree of demands in all of the three parts in the new form of the Czech state exam. The ability of a text production according to the task (e.g. by a given text, topic and processing it) is verified by a written composition work. In reading strategies, the pupil shows his ability during the right assigned topic (choice of 10 voluntary topics) to read the topic correctly, understand the task and required processing of the author's productive text. Some tasks are moreover completed by a given text which can have several forms: e.g. illustrative (the pupil can and doesn't have to inspire by the text, it is up to his will), informative (the pupil is obliged to work with the information expressed in the text), polemic (the pupil must prove his own opinion, think for example about the different stand points towards the issue in the text, express his own agreement or disagreement with the indication to solving problems or his). If the pupil doesn't understand the task and the process (at this phase a concrete composition is assigned - e.g. spelling, storytelling, reflection essay, an official letter and concrete communication situation - e.g. environment, time, issue etc.), then they don't fulfill sufficiently the productive part of the Czech state exam from the Czech Language and Literature, they don't fulfill the complex requirements of the Czech state exam. In the didactical text, the reading strategies are verified at the first place.

How the pupil understands the meaning of appellation, to what degree the pupil understands the whole text and its parts, to what degree the pupil analyzes construction of the 
statement and the text, how the pupil is able to compare or recognize the texts in one text by using another text, how the pupil uses interdisciplinary connections etc. In the sub-verbal exam, the pupil works with a work sheet having two texts as its part: excerpt from the artistic and an excerpt from the non-artistic text as well as a general or developed form of an exam structure. In the Catalogue of requirements for examinations with a common part for the Czech state examination from the Czech Language and Literature, 2016 (part C) [1] presents examples of exam tasks, examples of the written assignments and examples of the work with the work sheets for the Czech state exam from the Czech Language and Literature. In comparison to the exam tasks in the past years, with regard to the actual form of expected outputs of the assignments for 2016, an increase of open tasks, accuracy of enumeration exam facts in the area of theory and history of literature has occurred (by publishing the suggested list of required literary concepts - e.g. literary world trends, representatives of literature, literary work and concepts from the area of literature theory).

Illustrative closed task (3) from the didactical Czech state exam test in the Catalogue of requirements (2016) portrays a work of a pupil (reader) with the given text. The task for the pupil is to first of all mechanically read the text, understand the meaning of the text for example by key words: Egypt, monumental construction, mastaba, temples, rulers and monarchs. The assignment of the exam question is directed towards a linguistic issue. It is about recognizing a spelling mistake in the text and determining the area (choosing out of four options), where the spelling flaw is occurring. Even though this type of question is considered to be the easiest from the solution demanding point of view (correctly it is placed to very first tasks of testing (going from the simple tasks to the more complicated ones) in the international inquiries on the reading literacy as well as in the entrance exams to Czech high schools), lots of pupils make mistakes in those. There can be more than one reasons for this. It could go from inattentive reading of the text and the task assignments to prevailing linguistic (factual, conceptual and expert) knowledge deficiency in the area of adjective declination etc.

Illustration of the assigned task [1]

\section{“TEXT FOR TASK 3}

Arts in Egypt served as a culture of the dead rulers but it also emerged as a need for an organization of economy. Architecture of Ancient Egypt rested on monumental stone constructions. Temples, tombs, mastabas and pyramids were being built. Mastabas were aboveground parts in the shape of a truncated pyramid. They were decorated by statues, reliefs and wall paintings and they had up to 32 rooms. Temples (Karnak, Luxor, Véset) rose to worship Gods, usually an avenue of Sphinxes lead to them. Those temples also included colossal statue of pharaohs, pillared halls and pillared rooms, only Egyptian priests could enter them. (www.egyptane.cz, adjusted)

\section{In which of the following areas is a spelling mistake in the text? \\ A) Writing of capital letters \\ B) Adjective endings \\ C) Writing of consonantal clusters \\ D) Match predict to give a cause \\ Option: B) " [1], pg. 13}

For high school students, teachers and pedagogical (as well as non-pedagogical) public, all of the information about the concept and organization of the Czech state examination from Czech Language and Literature (including key information of the effective curriculum educational documents) are available at CERMAT (www.novamaturita.cz).

"A methodological didactical help for high school teachers are LMS CERMAT pages, where individual educational modules (expert methodology and

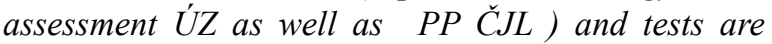
published, leading to obtain a teacher's role (by the form of e-learning and full-time study and followed by a certified exam), assessor of oral exam and assessor of written work. From 10.11.2014 educational modules are saved here, also including the attachments for the current basic course on the role of an assessor of oral and written exams from the Czech Language and Literature (for intact as well as for disabled students). Methodology of the above mentioned educational models is in compliance with the methodology of testing tasks of international surveys on reading literacy." [12], pg. 54-55

\section{Discussion}

The PISA research requires from a fifteen-years-old skills: to search for information, to decipher the main author's thought and goal, to connect pieces of information from the text with own experience and attitudes. The goal is to understand the text with regard to individual and age limitations.

The PIAAC research requires from adult reader skills: to search, to organize, several pieces of onformation, to process them and to evaluate them without reading difficulties. The goal is to understand the text- functional literacy.

This research of the new Czech curriculum concept highlights the importance of text understanding in view of functional literacy with augmenting the understanding in the interpretative level. It is mainly the development of cognitive, emotional and social processes in lifelong learning. The research suggests that better reading can be developed not only in childhood (Elementary school), but also in adulthood. A good reader can improve his/her reading skills independently of his/her age. However a well elaborate concept of education helps with an effective training of the reader. 
The research opens a discussion about the search for ways to develop reading literacy by applying methods from the international research of reading literacy PISA and PIAAC into the Czech curriculum. A mature reader can independently of his age critically evaluate the text, create general and professional hypothesis and interpret his own opinions and opinions of other authors.

\subsection{Czech Pedagogical Reality and Outputs of International PISA and PIAAC Surveys}

The conclusion from the survey is that in the Czech education system, the continuity of requirements from the reading education point of view especially at the border age period of the pupil at the transition from the primary education to a high school and at the same time by the end of the high school education, is not being thought through sufficiently. A convenient incentive in the development seems to be the introduction of the unified entrance exams to high schools from the Czech Language and Literature subject. At the current Czech pedagogical reality, this trend indicates the maintenance of individual requirements of the level of knowledge of a mother language and literature of fifteen years old pupils. Education of a good reader also rests in enhancing teachers support in the productive work with a text. In reading strategy education tasks concentrated on reproduction of a text should not be the only ones prevailing. In an active, open and modern school, the student should know how to work with information, the student should master the reading strategies in connection to the international surveys on reading literacy across the age (finding out information, processing the information and assessing the information). During lecturing the students as well as teachers should work with students' pre - concepts, comparing the students' experiences, comparing the information work with the diverse text material (with consistent and inconsistent texts, artistic and non-artistic texts), work with methods of critical thinking, develop the skill to predict as well as to generalize [13].

From the outputs of the international survey on reading literacy (PISA, 2009), the existence of significant differences among schools in the Czech Republic is apparent. Demonstration of the selective educational system indicates the contradictory perception on the equal opportunities in education for all students. "In the Czech Republic the differences within the schools are below the average (OECD average is $63 \%$ ), whereas the differences among the schools are above the average (OECD average is $42 \%)$ " [7], pg. 31. It has been concluded from this information that in the Czech Republic students with similar sociocultural background usually gather in schools (influence of the family, residency, manner of admission process, school curriculum). Furthermore, it can be stated that the function of the education system expresses itself with a great selective characteristic. "In the Czech Republic the influence of the average sociocultural background of a school is the second biggest influence in the OECD countries" [7], pg. 31 .

"From 2000 until 2009, the results in reading literacy of pupils from primary schools and students in the Czech state exam programs as well as in vocational training programs of high schools and vocational training schools had significantly worsened. The difference between the results of the above mentioned students and the students of high grammar schools, whose results had practically not changed, had been deepened. On the contrary the results of the students from special schools had been significantly better" [7], pg. 36.

In the test of the reading literacy (PISA, 2009), the Czech fifteen years old students in comparison to other OECD countries were placed in the last third of the arranged criteria. The number of students portraying stigmas of future problems in being successful in life has risen. Particularly deteriorating boys participate at the deterioration of the results of the Czech students. As part of the internationals survey (PISA, 2009), the further findings are that more than a half of the examined sample of pupils are being bored at school and one third of pupils doesn't want to attend a school. The number of pupils reading just for fun has declined. The discipline during the Czech language lecture has worsened as well.

From the above mentioned, in our further research survey our intent is to dedicate ourselves to mapping different ways of lecturing among a variety of schools as well as within the schools.

\subsection{Marking out Problematic Questions with Regard to Education in Reading}

We are interested at the teaching activity, teaching source and other selected factors which can influence the level of reading literacy in the Czech Republic. A very significant finding for us is to what extent the Czech teachers of a mother language are informed about the outputs of the international surveys on reading literacy across the varying age categories $[8,12,13]$. What effective reading strategies and teaching strategies are prevailing during a lecture, if bringing improved results in reading? Do the teachers know which manner of teaching is convenient for a concrete target group of pupils? Do teachers involve in their lectures different types of activities involving sensory perception (hearing, visual, kinetic, relaxing, combination of exercises)? Does the same information appear during the lecture repeatedly in another form? Do teachers and students use appropriate tools (mind maps, auditory anagrams, timeline, mnemonics tools, crosswords, brain teasers and others)? To what extent is it effective to test students in specific reading strategies?

\subsubsection{How to tackle difficulties in reading strategies?}

To remove gained reading habits and to overcome possible reading difficulties is not easy. During the teaching of reading strategies at school or outside of school it is appropriate to target the text comprehension (by asking 
questions, searching for key words, matching pictures to concepts, looking for differences and similarities in the text, dramatization, playing out real life roles). The choice the right reading technique, sharing reading (by creating own thoughts, argumentation, sharing of reading experiences and facts in a team, cooperation activity, project activity and others) is important. In case students do understand the text, they can assess the information gained from the reading (their truthfulness or non-truthfulness). In this phase of teaching and the choice of the reading strategies we are talking about modeling, creating an own opinion about an issue. A good teacher should be able to create proper, positive and motivating environment (atmosphere and climate) leading to an effective application of theoretical facts to a practical life (e.g. using the methods of critical thinking). A positive attitude to reading is fulfilled in case the student is mastering a sufficient database of reading strategies which lead to the understanding of what have been read, processing and assessing gained information. The possibility to share reading experiences and their application to everyday communication situation seems to appear to be crucial.

In the Czech education system amendments are being prepared in the conception of the admission process of pupils from primary to high school education by the running of a two years pilot testing of unified entrance exams since 2014/2015, which verify the determined level of the grade 9 graduates in the field of the Czech Language and Literature knowledge and as its part is also the testing of the reading literacy level. The aim is to introduce a unified system of the admission process for all high schools with the Czech state examination. The responsible organization for piloting this project is the same organization CERMAT (Center for preparation of the Czech state exam, www.novamaturita.cz) [1], which prepares the concept of the current form of the Czech state examination from Czech Language and Literature. Unification in the concept of testing of the expected outputs from the teaching of a mother language from a primary and a high school is an important step to implement the continuity of the whole education concept (of the Czech pedagogical reality) in connection with the results of the international survey on reading literacy $[8,13]$.

\section{Conclusions}

From the survey of the current pedagogical reality in the field of reading literacy anchored in the current educational curriculum Framework Educational Program Czech Language and Literature for Basic Education as well as Framework Educational Program for grammar high schools and Standards, a conclusion is drawn that a gradual reflection of the outputs of international surveys on reading literacy (PISA i PIAAC) is being implemented. A convenient political and expert knowledgeable decision appears to be the gradual introduction of compulsory didactical tests from the Czech Language and Literature within the transitional framework from a primary education to a high school education which is being terminated by completing a Czech state examination. A positive outcome can be seen in the unified concept of the admission process being prepared (for the time being in the two years pilot phase of the exam testing of fifteen years old pupils). We perceive this trend as a continuity on the international survey outputs of the reading literacy PISA, 2009 [13]. Up to nowadays, schools and the regions could decide themselves whether they will join the pilot introducing the unified entrance exams from the Czech Language and Literature, or whether they choose another (their own) version of a structure and a manner of entrance exams.

A positive finding is also the compulsory introduction of a new form of the Czech state examination at the end of a studying term at high schools, as its part is verifying the level of reading literacy by working with a text (in all of the parts of the Czech state examinations from the Czech Language and Literature). This phase is seen as the continuity on the international survey outputs of the reading literacy PISA, 2009 and PIAAC, 2011, 2012 [13]. The aim of our further survey is to follow the development of the Czech curriculum in the area of reading literacy in connection with the development of the European and the world's educational concept (via further international surveys on reading literacy in the near future). Introduction nationwide of the compulsory testing of fifteen years old Czech pupils as well as students attending high schools in the field of reading strategies is an example of good pedagogical practice.

Gaps may be seen in the everyday work of teachers and pupils during the lecture of the Czech Language dedicated to the education of a reader and functional reading strategies. Within the pedagogical reality in the field of education in reading strategies, we perceive the level of Czech Language textbooks especially at the $2^{\text {nd }}$ level of a primary school and in a high school as a weak place.

Our onward research will be dedicated to the aforementioned issue in our further survey on the education of a reader. This paper perceives functional literacy in connection with the social, economic, cultural level of developed countries. It is evident that functional literacy is connected to the ability to communicate and is perceived as a fundamental continuum which is measurable and interpretable. The level of cultural context of the society is a reflection of functional literacy of the inhabitants of the given country at a particular time.

\section{Acknowledgements}

This paper was prepared with the help projects: IGA_PdF_2015_022 The phenomena of relationships between education and thinking in constructivism education; IGA_PdF_2016_010 The role of teacher in global world.

Internal grant of PDF UP in Olomouc: From subjective 
implicit theories of education to teaching knowledge. The process of constitution of a cognitive framework sciences education in the national and international context.

Publishing of this article was supported by the project and the authors would like to give thanks for the given support.

\section{REFERENCES}

[1] Katalog požadavků zkoušek společné části maturitní zkoušky z českého jazyka a literatury 2016-2014 www.novamaturita.cz

[2] J. Průcha. Pedagogická encyklopedie. Praha: Portál, pg. 67, 2009.

[3] I. Procházková. Sympozium PISA v Berlíně - zpráva ze zahraniční služební cesty. Praha: Univerzita Karlova, 2002.

[4] P. Gavora. Žiak a text. Bratislava: Slovensképedagogické nakladatelstvo, pg. 21, 1991.

[5] L. Liptáková a kol. Integrovaná didaktika slovenského jazyka a literatúry. Prešov: PdF v Prešovské univerzity v Prešově, pg 204-205, 2011.

[6] L. Huffman, S. Mehlinger, A. Kerivan. Risk factors for academic and behavioral problems at the beginning of school. In off to a good start. Research on the risk factors for early school problems and selected policies affecting children's social and emotional development and their readiness for school. Chapel Hill: University of North Carolina, 2000.

[7] J. Palečková, V. Tomášek, J. Basl. Hlavní zjištění výzkumu
PISA 2009: umíme ještě číst? Praha: Ústav pro informace ve vzdělávání, 2010.

[8] MŠMT. Zveřejnění prvních výsledků výzkumu OECD PIAAC, 2013. Online available from: http://www.msmt.cz/ministerstvo/novinar/zverejneni-prvnic h-vysledku-vyzkumu-oecd-piaac

[9] MŠMT. Standardy pro základní vzdělávání. Praha: MŠMT, pg. 31-37, 2013. Online available from: http://clanky.rvp.cz/clanek/c/Z/17383/STANDARDY-VZD ELAVACICH-OBORU-ZAKLADNIHO-VZDELAVANI--VEREJNE-PRIPOMINKOVE-RIZENI.html/OECD (2005) Formative Assessment - Improving Learning in Secondary Classrooms. Paris: OECD, 2005.

[10] MŠMT. Upravený rámcový vzdělávací program pro základní vzdělávání platný od 1.9.2013. Praha: MŠMT, 2013. Online available from: http://www.msmt.cz/vzdelavani/upraveny-ra mcovy-vzdelavaci-program-pro-zakladni-vzdelavani

[11] J. Zíka. Souhrnná závěrečná zpráva. Praha: MŠMT, 2015. Online available from:

http://www.cermat.cz/souhrnna-zprava-2015-a-2016-140403 5215.html

[12] D. Vicherkova, P. Kaduchova. Medzinárodné výskumy čitatel'skej gramotnosti u detí (PISA) a dospelých (PIAAC) ako výzva pre učitel'ov i veřejnost. Motus in verbo: vedecký časopis mladej generácie. Bánská Bystrica: FF Univerzita Mateja Bela, 44-58, 2015. ISSN 1339-0392

[13] Ústav pro informace ve vzdělávání. Měření vědomostí a dovedností: nova koncepce hodnocení žáků. Praha: Ústav pro informace ve vzdělávání, 1999. Online available from:http://www.csicr.cz/getattachment/cz/O-nas/Mezinarod ni-setreni-archiv/PISA/PISA-2000/Mereni-vedomosti-a-dov ednosti-publikace.pdf 